\title{
Non-Communicable Diseases in Indonesia: Prevalence and Risk Factor
}

\author{
Resafina Melinda Sadomo' ${ }^{1}$, Lukman Fauzi ${ }^{2}$ \\ \{resafinams@gmail.com¹ ${ }^{1}$ lukman.ikm@mail.unnes.ac.id² \\ Universitas Negeri Semarang, Semarang, Indonesia ${ }^{1,2}$
}

\begin{abstract}
Non-Communicable Diseases (NCDs) were the leading causes of death in Indonesia. According to the 2018 data from WHO - NCD Country Profile, the proportional mortality in Indonesia were cardiovascular diseases $(35 \%)$, cancers $(12 \%)$, chronic respiratory diseases $(6 \%)$, diabetes mellitus (DM) $(6 \%)$, injuries $(6 \%)$, other NCDs (15\%), and communicable maternal, perinatal, and nutritional conditions (21\%). The aim of this study was to find out the prevalence of NCDs of each province in Indonesia and physical inactivity as a risk factor of NCDs. It was descriptive study based on Basic Health Research 2013 and 2018. Data 2018 revealed that most of NCDs such as stroke, cancer, and DM increased from 2013. The proportion of physical inactivity in Indonesia increased from $26.1 \%$ in 2013 to $33.5 \%$ in 2018. Perhaps there was association between physical inactivity and the incidence of NCDs. Further study was needed to analyze the risk factors associated with NCDs.
\end{abstract}

Keywords: Non-Communicable Diseases, Prevalence, Risk Factor, Physical Activity, Basic Health Research.

\section{Introduction}

Non-Communicable Disease (NCD) was a chronic disease, not human to human transmitted, had long duration and normally grows slowly. NCDs had become the leading cause of death globally at this time [1-3]. According to the 2018 data from WHO - NCD Country Profile, the proportional mortality in Indonesia were cardiovascular diseases (35\%), cancers $(12 \%)$, chronic respiratory diseases $(6 \%)$, diabetes mellitus (DM) $(6 \%)$, injuries $(6 \%)$, other NCDs (15\%), and communicable maternal, perinatal, and nutritional conditions $(21 \%)$ [4]. Based on data from Basic Health Research 2018, most of NCDs such as stroke, cancer, and DM, showed an increasing trend compared to the previous report in 2013.

Cancer was the growth of uncontrollable cells/tissues [5,6]. They continually grow, immortal. Cancer cells can penetrate to the surrounding tissues and can form subset $[4,7,8]$. The incidence rate of cancer in Indonesia (136.2 / 100,000 population) ranks 8th in Southeast Asia, while in Asia it is 23rd. The highest incidence rate in Indonesia for men was lung cancer, which is 19.4 per 100,000 population with an average mortality was 10.9 per 100,000 population, followed by liver cancer at 12.4 per 100,000 population with an average death rate of 7.6 per 100,000 population. While the highest incidence rate for women was breast cancer, which is 42.1 per 100,000 population with an average death rate of 17 per 100,000 population followed by cervical cancer at 23.4 per 100,000 population with an average death rate of 13.9 per 100,000 population [9]. 
Stroke was disease to the brain causing local and/or global nerve malfunction, attacking unexpected, progressive and fast [10-12]. This disturbed nerve function was due to disruption to non-traumatic brain blood circulation $[13,14]$. It caused symptoms of: numbness of face or limbs, trouble speaking, unclear speaking, trouble understanding, blurred vision, etc [4]. The highest rates of stroke were observed in Mongolia (222.6/100,000 person-years) and Indonesia (193.3/100,000 person-years), followed by Myanmar and North Korea [15].

DM was a metabolic disease constituting a group of symptoms suffered by someone as a result of high blood sugar above normal rate [16-18]. This disease was due to disturbed sugar metabolism resulting from lack of insulin in terms of absolute and relative [19-21]. There were 2 types of DM, to wit: Type I/Juvenile Diabetes, which normally attacks since juvenile period and Type II, i.e. diabetes attacking at adult ages [4].

The rise in NCD was mainly driven by four main risk factors: tobacco use, physical activity, harmful alcohol use and unhealthy diet [22]. Strenuous physical activity was physical activity carried out for $>3$ days per week and MET minutes per week> 1500 (MET minute value for strenuous physical activity $=8$ ). MET was a unit of energy expenditure and was used to measure physical activity in minutes [23]. MET minute was a unit used to measure the volume of an individual's physical activity. Moderate physical activity was moderate physical activity carried out for $>5$ days a week with an average length of activity $>150$ minutes a week (or> 30 minutes per day) [23].

Basic Health Research, showed the proportion of physical inactivity in Indonesia is $26.1 \%$ in 2013 and $33.5 \%$ in 2018. In 2013, there were 22 provinces whose population's physical activity was classified as less active with a proportion above the national average, including in Lampung Province which is $33.9 \%$ and 21 provinces in 2018 [4]. Based on the data above, the aim of this study was to find out the prevalence and risk factor of NCDs.

\section{Methods}

This study was descriptive study based on Basic Health Research 2013 and 2018. We analyzed the prevalence of cancer, stroke, and diabetes as well physical inactivity in 2018 compared to 2013. We used prevalence (\%o and \%) to describe the magnitude of NCDs and physical inactivity in Indonesia and each province from Basic Health Research 2013 and 2018.

\section{Result and Discussion}

\subsection{Prevalence of Cancer by Province (\%o)}

Based on Basic Health Research data, the prevalence of cancer in Indonesia showed an increase from (1.4\%o) in 2013 to $(1.79 \%$ ) in 2018. The highest cancer prevalence in 2018 was in DI Yogyakarta province with $(4.86 \%$ ), followed by West Sumatra with $(2.47 \%$ ) and Gorontalo with $(2.44 \%$ ). The lowest cancer prevalence was West Nusa Tenggara Province with $(0.85 \%)$ in 2018 [23]. 




Fig 1. Prevalence of Cancer by Province (\%o)

\subsection{Prevalence of Stroke by Province (\%o)}

Based on Basic Health Research data, the prevalence of stroke in Indonesia showed an increase from (4.5\%) in 2013 to (10.9\%o) in 2018. The highest stroke prevalence in 2018 was in East Kalimantan province with (14.7\%o), followed by DI Yogyakarta (14.6\%) and North Sulawesi (14.2\%) in 2018. The lowest stroke prevalence in 2018 was Papua with $(4.1 \%$ ) in 2018 [23].

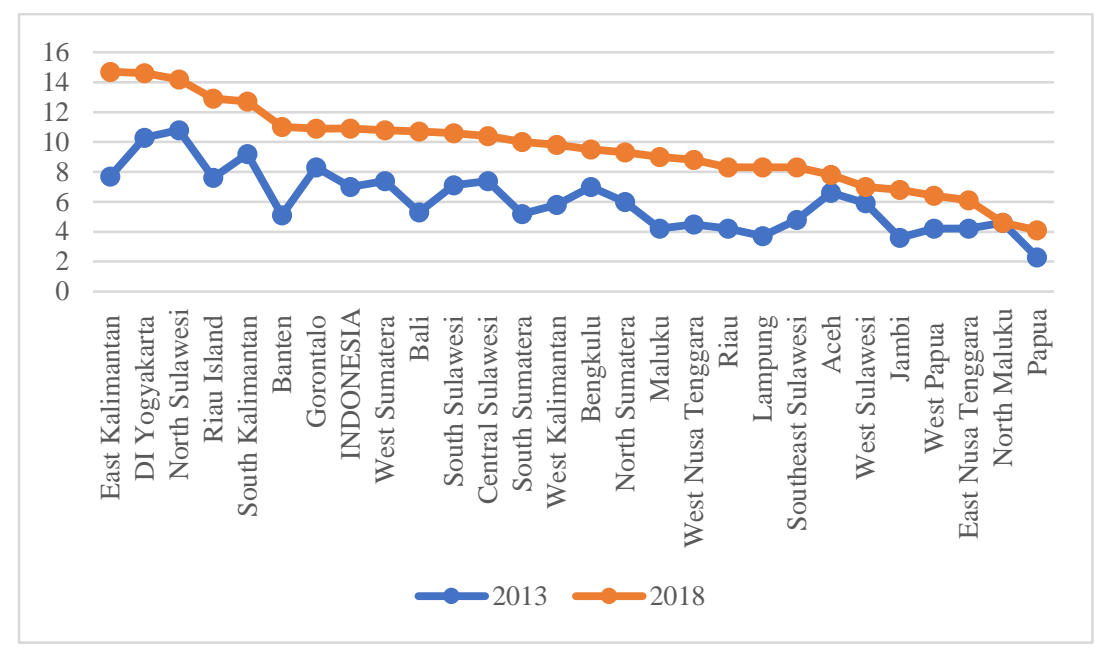

Fig. 2. Prevalence of Stroke by Province (\%o) 


\subsection{Prevalence of DM by Province (\%)}

Based on Basic Health Research data, the prevalence of DM in Indonesia showed an increase from (1.5\%) in 2013 to (2\%) in 2018. The highest DM prevalence in 2018 was in DKI Jakarta province with (3.4\%), followed by DI Yogyakarta with $(3.1 \%)$ and North Sulawesi province with $(3 \%)$ in 2018. The lowest DM prevalence was East Nusa Tenggara province with $(0.9 \%)$ in 2018 [23].



Fig. 3. Prevalence of DM by Province (Per \%)

\subsection{Proportion of Physical Inactivity by Province (Population> 10 years old)}

Based on Basic Health Research data, the proportion of physical inactivity in Indonesia showed an increase from $26.1 \%$ in 2013 to $33.5 \%$ in 2018. The highest proportion of physical inactivity was in DKI Jakarta province with $47.8 \%$, followed by Maluku province $42.5 \%$ and Jambi province $42.4 \%$ in 2018 . The lowest proportion of physical inactivity was East Nusa Tenggara province with $25.2 \%$ in 2018 [23]. 


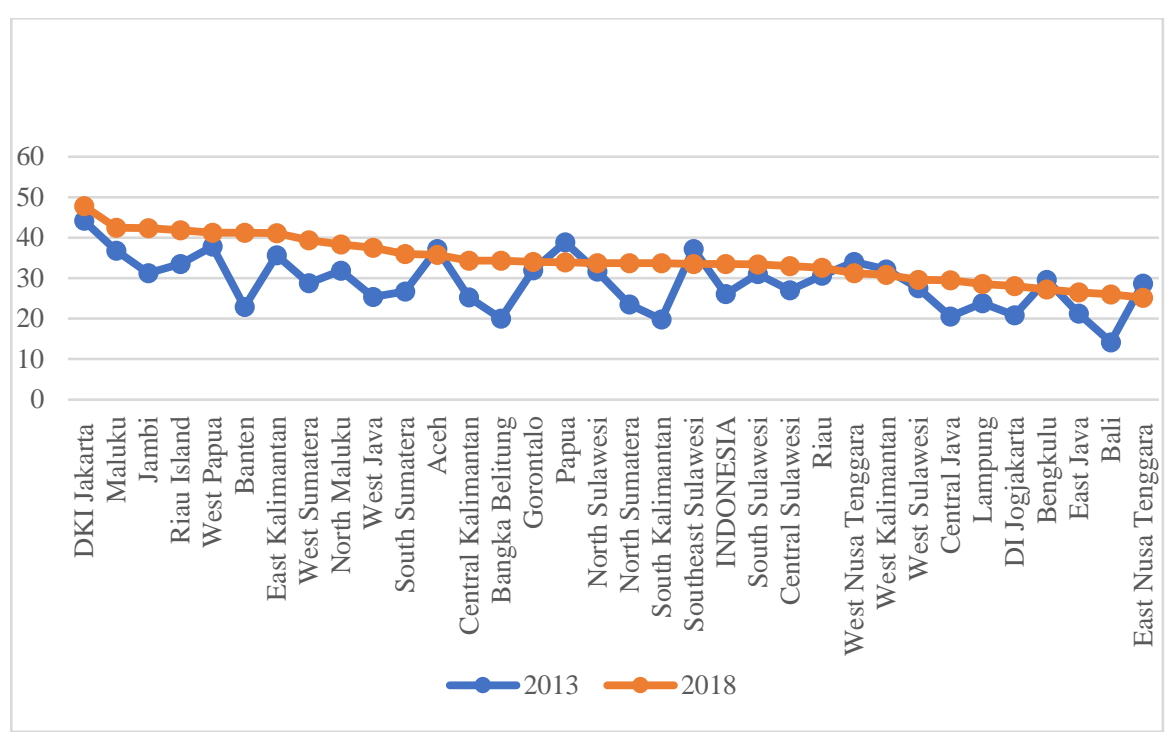

Fig. 4. Proportion of Physical Inactivity by Province (Population>10 years old)

\section{Conclusion}

The prevalence of NCDs (cancer, diabetes, and stroke) in Indonesia in 2018 has increased from 2013. DKI Jakarta is the province with the highest prevalence of NCDs, i.e. cancer $(2.33 \%)$, stroke (12.2\%o), DM (3.4\%), as well as the highest of physical inactivity $(47.8 \%)$ in 2018 in Indonesia. East Nusa Tenggara is the province with the lowest prevalence of NCDs, i.e. cancer $(1.49 \%)$, stroke $(6.1 \%)$, and DM $(0.9 \%)$, as well as with the lowest proportion of physical inactivity (25.2\%) in 2018 in Indonesia. Perhaps there is association between physical inactivity and the incidence of NCDs.

\section{References}

[1] NCD Countdown 2030: worldwide trends in non-communicable disease mortality and progress towards Sustainable Development Goal target 3.4. Lancet (London, England) 2018;392:1072-88. https://doi.org/10.1016/S0140-6736(18)31992-5.

[2] Shilton T, Champagne B, Blanchard C, Ibarra L, Kasesmup V. Towards a global framework for capacity building for non-communicable disease advocacy in low- and middle-income countries. Glob Health Promot 2013;20:6-19. https://doi.org/10.1177/1757975913501208.

[3] Benziger CP, Roth GA, Moran AE. The Global Burden of Disease Study and the Preventable Burden of NCD. Glob Heart 2016;11:393-7. https://doi.org/10.1016/j.gheart.2016.10.024.

[4] KEMENKES RI. Basic Health Research 2013, Jakarta: MINISTRY OF HEALTH OF REPUBLIC OF INDONESIA; 2013.

[5] Goral V. Pancreatic Cancer: Pathogenesis and Diagnosis. Asian Pac J Cancer Prev 2015;16:5619-24. https://doi.org/10.7314/apjcp.2015.16.14.5619.

[6] Torre LA, Islami F, Siegel RL, Ward EM, Jemal A. Global Cancer in Women: Burden and Trends. Cancer Epidemiol Biomarkers Prev a Publ Am Assoc Cancer Res Cosponsored by Am Soc Prev Oncol 2017;26:444-57. https://doi.org/10.1158/1055-9965.EPI-16-0858. 
[7] van den Bulk J, Verdegaal EM, de Miranda NF. Cancer immunotherapy: broadening the scope of targetable tumours. Open Biol 2018;8. https://doi.org/10.1098/rsob.180037.

[8] Berger MF, Mardis ER. The emerging clinical relevance of genomics in cancer medicine. Nat Rev Clin Oncol 2018;15:353-65. https://doi.org/10.1038/s41571-018-0002-6.

[9] Direktorat Jenderal Pencegahan dan Pengendalian Penyakit. Penyakit Kanker di Indonesia Berada Pada Urutan 8 di Asia Tenggara dan Urutan 23 di Asia n.d.

[10] Katan M, Luft A. Global Burden of Stroke. Semin Neurol 2018;38:208-11. https://doi.org/10.1055/s-0038-1649503.

[11] Barthels D, Das H. Current advances in ischemic stroke research and therapies. Biochim Biophys Acta Mol Basis Dis 2020;1866:165260. https://doi.org/10.1016/j.bbadis.2018.09.012.

[12] Dardiotis E, Aloizou A-M, Markoula S, Siokas V, Tsarouhas K, Tzanakakis G, et al. Cancerassociated stroke: Pathophysiology, detection and management (Review). Int $\mathrm{J}$ Oncol 2019;54:779-96. https://doi.org/10.3892/ijo.2019.4669.

[13] Knight-Greenfield A, Nario JJQ, Gupta A. Causes of Acute Stroke: A Patterned Approach. Radiol Clin North Am 2019;57:1093-108. https://doi.org/10.1016/i.rcl.2019.07.007.

[14] Venketasubramanian N, Yoon BW, Pandian J, Navarro JC. Stroke Epidemiology in South, East, and South-East Asia: A Review. J Stroke 2017;19:286-94. https://doi.org/10.5853/jos.2017.00234

[15] Venketasubramanian N, Yoon BW, Pandian J, Navarro JC. Stroke epidemiology in south, east, and south-east asia: A review. J Stroke 2017;19:286-94. https://doi.org/10.5853/jos.2017.00234.

[16] Kurniawan AH, Suwandi BH, Kholili U. Diabetic Gastroenteropathy: A Complication of Diabetes Mellitus. Acta Med Indones 2019;51:263-71.

[17] Berbudi A, Rahmadika N, Tjahjadi AI, Ruslami R. Type 2 Diabetes and its Impact on the Immune System. Curr Diabetes Rev 2020;16:442-9. https://doi.org/10.2174/1573399815666191024085838.

[18] Pulungan AB, Fadiana G, Annisa D. Type 1 diabetes mellitus in children: experience in Indonesia. Clin Pediatr Endocrinol Case Reports Clin Investig Off J Japanese Soc Pediatr Endocrinol 2021;30:11-8. https://doi.org/10.1297/cpe.30.11.

[19] Rusdiana, Savira M, Amelia R. The Effect of Diabetes Self-Management Education on Hba1c Level and Fasting Blood Sugar in Type 2 Diabetes Mellitus Patients in Primary Health Care in Binjai City of North Sumatera, Indonesia. Open Access Maced J Med Sci 2018;6:715-8. https://doi.org/10.3889/oamims.2018.169.

[20] Amelia R, Harahap NS. Stroke among Type 2 Diabetes Mellitus Patients at Haji Adam Malik General Hospital, Medan, Indonesia. Open Access Maced J Med Sci 2019;7:2643-6. https://doi.org/10.3889/oamjms.2019.743.

[21] Utami DB, Findyartini A. Plant-based Diet for HbA1c Reduction in Type 2 Diabetes Mellitus: an Evidence-based Case Report. Acta Med Indones 2018;50:260-7.

[22] WHO. Noncommunicable diseases n.d. https://www.who.int/health-topics/noncommunicablediseases\#tab=tab_1.

[23] KEMENKES RI. Basic Health Research 2018. 2018. 